\title{
Main topics and discussions on ancient Greek houses of West Anatolia
}

\author{
H. Gönül \\ Department of Architecture, Mimar Sinan Fine Arts University, \\ Istanbul, Turkey
}

\begin{abstract}
The controversial research topics on ancient Greek houses of West Anatolia can be examined in three main categories; origins and development of house typologies; definition of home space and it's analysis in terms of structure, function and location; and relation between society and domestic architecture.

The origins of space division of Classical houses are attributed to different traditions but usually limited archeological finds are not enough to prove these opinions. The houses of Classical Period have been classified as the "prostas house" and the "pastas house" after the first wide-ranged excavations. However, later excavations revealed new examples independent from both categories.

Social and political structure is also found helpful to explain the organization of house space. However, the structure of Ancient Greek society is not clear in all aspects, yet some social evaluations like gender studies are usually tried to be explained by means of house organization contrarily.

The inadequacy and heterogeneity of archeological remains, the classifications made without justified finds and the nature of domestic architecture that it is bound to individual initiative much more than public buildings are the basic reasons of the controversial topics.

Keywords: ancient domestic architecture, ancient Greek house, houses of West Anatolia, Ionian house, Lydian house, Classical Greek house, prostas house, pastas house.
\end{abstract}

\section{Introduction}

This paper aims to criticise the studies on Ancient Greek houses of West Anatolia dated between 11th and 4th Century AD. Time span after 4th Century is 
out of concern because in regard to the former eras, the housing types of Hellenistic period are more homogenized, ascribable to the strengthening of Panhellenism idea. Also, the archaeological ruins from this period are better in both quality and quantity, so the controversial topics are minimised.

The discussions on Ancient houses concentrate on three main topics, which are; the origins and development process of housing typologies in terms of building traditions; characteristics of home space and it's analysis in terms of structure, function and location; and the relation of house space to social and political structure. Especially these concerning the definition of housing space and it's relation to social structure is not specific to West Anatolia, but valid for all Ancient Greek city-states.

\section{Origin and development issues}

Studies on the origins of Ancient houses mainly focus on the Classical era (5th 4th Century AD), especially because the houses of Archaic and Geometric Era (9th -8 th Century AD) do not show a unity to permit a general explanation as local customs and traditions are more influential on the formation of home space before 5 th Century.

First wide ranged excavation in search for houses was carried out by Theodor Wiegand and Hans Schrader in Priene during 1895-1898. As the 4th Century AD Priene houses were laid out according to same plan principles in rectangular house blocks of identical size (insulae), the investigators were able to identify a plan schema, which they named the "prostas house" [1].

Another grand excavation was led by David M. Robinson and J. Walter Graham in Olynthus, and they uncovered nearly 100 well-preserved houses dated to 5th Century AD. Also in Olynthus were explored houses designed by the same plan principles in identical insulaes, which were named the "pastas house" [2].
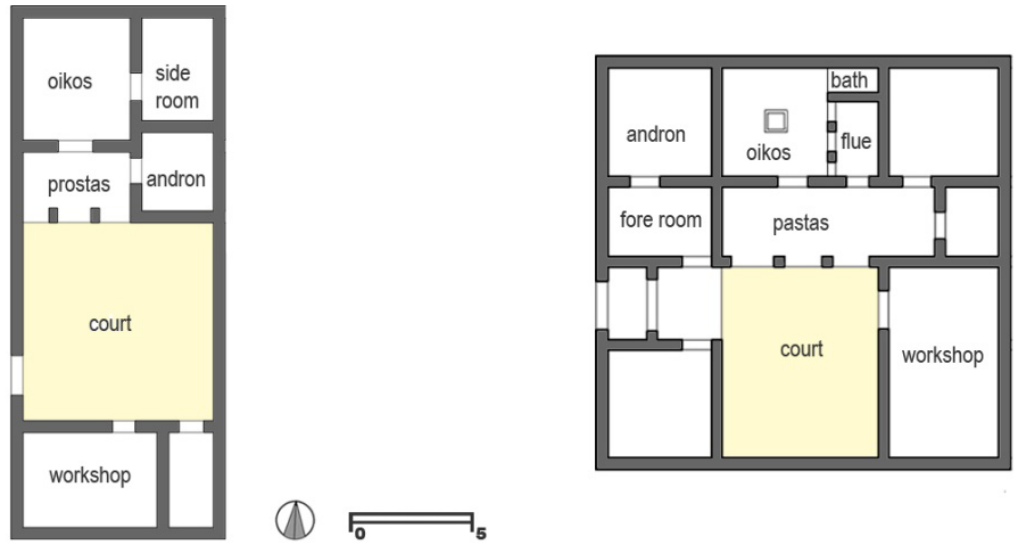

Figure 1: $\quad$ Prostas House in Priene and Pastas House in Olynthus. 
Prostas/pastas is the name of the semi-open space between the living room(s) and the court. The word prostas ( $\pi \rho 0 \sigma \tau \alpha \dot{\alpha})$ means "standing in front" while

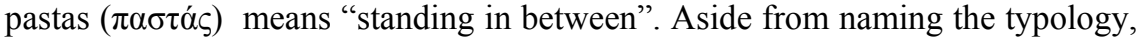
these spaces have no distinctive function. After the two great excavations mentioned above, examples of both types have been discovered in other cities, so these types have been generalized as a plan schema for the Classical Era house.

The houses of Classical Period have similar space organization whether they contain a prostas/pastas or not. For the Classical Greek house such a general definition can be made: the exterior door opens to the court directly or by the help of a vestibule. On one side -usually the north- of the court, are the living spaces (oikos), which are rectangular in plan and can be two-storey high. There can be the prostas/pastas in front of the oikos. Secondary rooms, workshops, shops, storage, if they exist are on the other sides of the court. The specific point about this type are that the circulation is by the help of the court while usually there is no access between rooms, and the oikos stand at the north of the court.

There are different views about the origin of this house organization, but usually researchers agree that it is the result of an expanded tradition, and look for traces of evolution examining the houses of 9th to 7th Century AD.

\subsection{Megaron}

The prostas house is considered to have developed from the megaron uniting with other rooms and a court [3-8]. This idea comes from the assumption that prostas and oikos together form a unit in megaron form, which exists in Anatolia since the Bronze Ages.

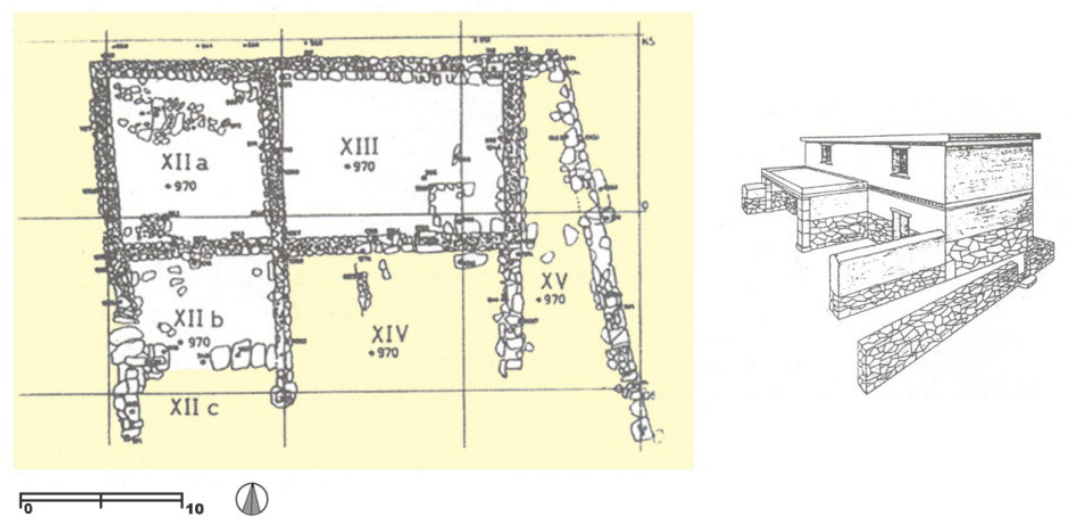

Figure 2: Double Megaron House in Bayrakl1 [4].

The "double megaron" house dated to 7th Century AD in Bayraklı near İzmir, is considered to be the first prostas house, and a milestone of the transition from megaron to prostas house. Akurgal [4] states that this houses consists of two adjacent megarons, the one at west preserving its original form while the one at 
east has been transformed to become more suitable for daily activities. Probably he points out that the east room, used as oikos, is wider and shorter than the classical narrow and long megaron form. Although this house is interpreted as two megarons side by side, Akurgal [4] also states that the east wall of the space $\mathrm{XIV}$ is added later to the building, which means the east part is not a megaron, but a rectangular room at the first construction phase. Then, the oikos of this house (the east room) is not in megaron form.

The "double megaron" house is interpreted as analogous with the 6th Century AD Onythe (in Crete) houses which also consist of adjacent megarons [9]. The southmost structure, which is considered as the first pastas house, comprises three megarons side by side opening onto a corridor [10]. Although the general opinion is that the pastas house has developed from the "wide house" used as cult rooms or housing units at Geometric Period [6, 11], Graham [10] argues that the pastas house could also have been evolved from megaron indicating this house in Onythe.

According to Akurgal [5] and Gürler [12], the megaron is a detached structure, therefore not suitable to form big house complexes with adjacent rooms, and this characteristic of it has prevented the development of Greek house at early ages, until the double megaron house. Whereas the megaron in relation with other rooms has formed house complexes in Late Minoan Age in Crete [13], and about $2100 \mathrm{AD}$ in Kültepe [14]. Akurgal defines three main stages at the development of prostas house from the megaron; the shortening of megaron, this short megaron forming a unit with adjacent rooms, and the addition of a court to the south [5]. Although Abbasoğlu [3] claims that these stages can be traced in Milet, Phokaia, Colophon and Priene, another early example has not been explored in any of these cities. The first organized prostas house in history emerges in Pire in 5th Century AD. There are no archaeological finds to fill the huge gap between Pire houses and the 7th Century so-called first prostas house in Bayraklı. On the contrary, the development of rectangular planed rooms surrounding a court can be traced in Klazomenai, Milet, Sardis, Latmos and Bayraklı in West Anatolia [15-19]. The archaeological remains indicate that the houses were mostly single roomed structures from 10th to 7 th Centuries, while during the Archaic ages, as the number of rooms increased, they were gathered around a court. The 7 th and 6 th Century houses do not comprise a megaron but rooms surrounding a court. Also, the living spaces of these houses are gathered at one side of the court, similar to the prostas house. Due to this evidence, Gürler [12], denies that the double megaron is the first phase of the prostas house, and indicates the 6th Century multi-room houses with courts in Bayraklı settlement as the first steps of prostas house.

Another argument is that the Classical prostas house pursues the grand hall tradition of Mycenaean palaces and aristocrat houses, pointing out the similarities between the oikos of prostas house and the megaron of Mycenaean Palace $[7,8]$. But there is a huge gap between first prostas houses of 5th Century $\mathrm{AD}$, and the Mycenaean palaces of 16 th to 13th Centuries AD. Besides, the megaron is used as the reception room in Mycenaean Palace, whereas it is the oikos in prostas house. 
Structural Repairs and Maintenance of Heritage Architecture XII 65

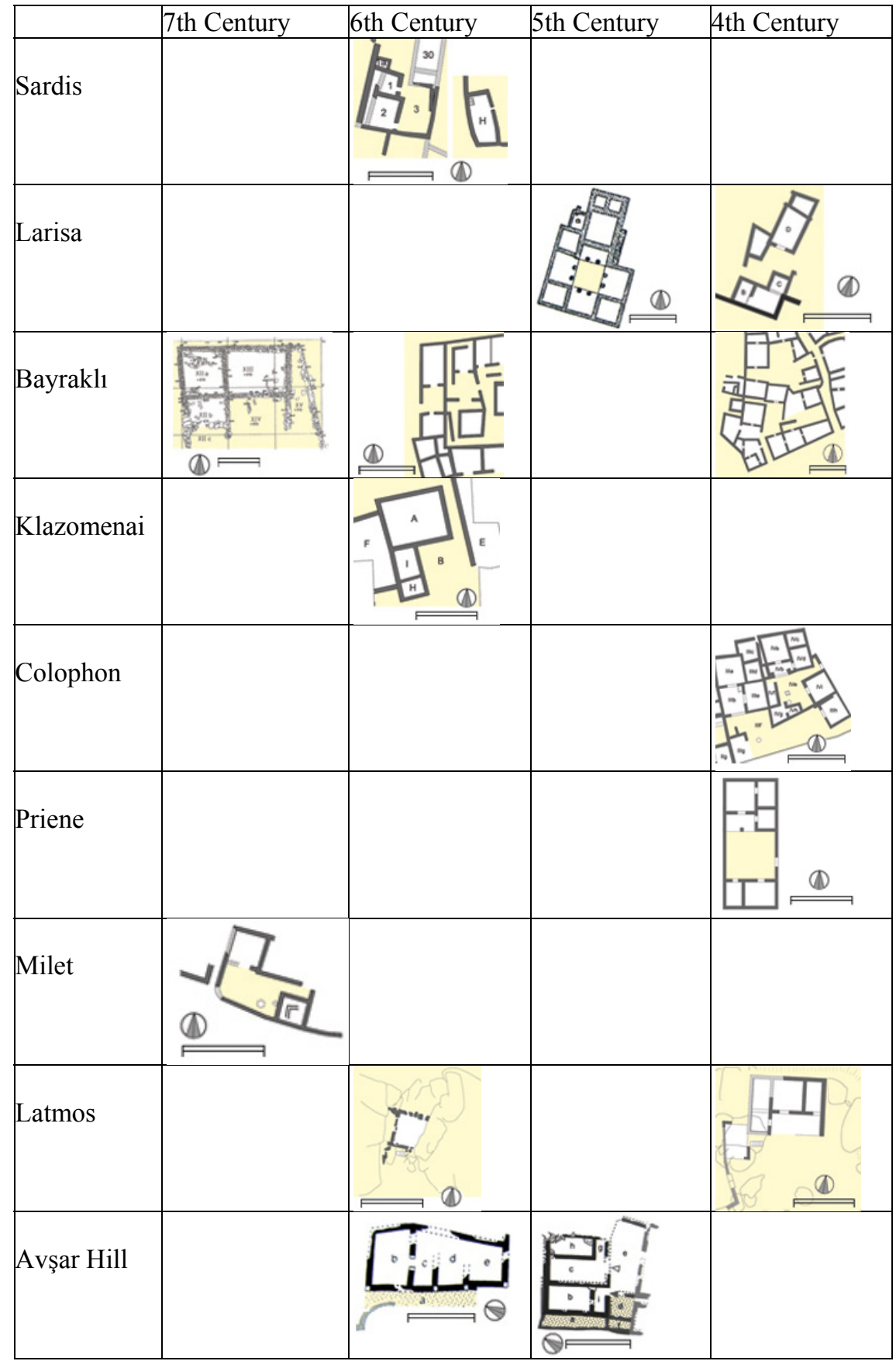

Figure 3: Ancient houses of West Anatolia (bar scale is 10 meters) $[4,15-22]$. 


\subsection{Eastern influences}

The Greek cities of West Anatolia had the opportunity to discover Ancient Egypt and Mesopotamian cultures, mostly due to their commercial relations. Additionally, although they were independent city-states, they were under the Lydian and Persian rule for centuries, which inevitably led to cultural encounter.

There stand out similarities between Mesopotamian and Greek houses in terms of andron and central court. At the houses of Babel and Ur, the court plays a central role just as in the Greek house, but in Mesopotamia the court is both functionally and physically the center of the house, whereas at the Greek house the court is not necessarily surrounded by rooms at four sides. Also the "men's quarter" of Mesopotamian house and the andron of Greek house show similarities not in terms of space organization but function. At 7th and 6th Century Babel houses, the men's' quarter is a complex consisting of several rooms, contrary to the Greek andron which is a single room, or a room and a fore room. But both spaces house the banquets of men and are separated from the rest of the house by the help of court [23]. Also the banquets, called symposion, and the custom of inclining on a kline (one armed couch) while eating, is adopted from East, most probably from Lydia [20].

Houses directly influenced by Eastern cultures are limited. These are mostly the palaces of satraps. The palace in Larisa, which is constructed around $550 \mathrm{AD}$, is a building of "hilani" plan type, totally influenced by Eastern tradition [22]. About the end of the 6th Century AD, a megaron was added to the west of the palace, at 5 th Century $\mathrm{AD}$, the court in front of the megaron was surrounded by rooms and columns in front at all sides [22]. So that the first peristyl court, which is one of the characteristics of Hellenistic house, has appeared in Anatolia with Persian influences. Another Persian influenced building is the house of the governor in Avşar Tepesi settlement in Lycia. This house is interpreted as the synthesis of bit-hilani type and Lycian local building traditions [24]. Besides these direct influences, it is also argued that the idea of connecting the andron, which is the reception room of the governor's house, and the living spaces around a court is adopted from the Persian palace tradition [25].

In Ancient house studies, the possible influences of Eastern civilizations are usually ignored, and the researchers try to explain the development of Greek house within itself. However, concrete examples reveal that some elements like the peristyle court, or the andron exist in other cultures before they have appeared in Greek domestic architecture. Besides, there are aspects like Ionian capitals or cut stone masonry that have developed under the influence of Mesopotamia or Egypt in Greek architecture [13], so it is also conceivable to evaluate Eastern influences in Greek domestic architecture.

\section{Space organization}

The prostas plan has been discovered in Priene, Colophon in Anatolia, and Pire, Abdera in Greece so far, while the pastas plan has been discovered in Latmos in Anatolia, and Olynthus in Greece. Both typologies, and houses except these 
types have similar space organization. The parts most encountered in the Classical era houses are the court, prostas/pastas, oikos and andron. In some cities the houses also contain bathroom and secondary rooms (storage, workshops, shops..). A gynaikonitis (women's' quarter) and thalamos (bedroom) is also considered to exist in the Greek house even though there is no archeological evidence to prove.

The court is the center of the house not physically but in terms of circulation and life. It connects the rooms with each other and outside.

Oikos is the main unit of the house, in Ancient Greek texts the word is also used for defining the "household". In single-room houses the house and the oikos are the same, and the family lives and sleeps in the same room. The oikos usually stands on the north of the court so that it benefits from the sun utmostly $[3,7]$.

The banquet which the male household hosts their male friends are called "symposion". There has developed separate rooms for these fests, probably because the male quests cannot enter the living spaces of the house [20]. The andron is thought to have emerged in the house of the aristocrats in Ionia about 7th Century AD, and has been widespread through the 5th Century [20]. The androns are the most outstanding rooms in the house with their elaborate decoration. In Olnythos the floors of some androns are paved with mosaics. Another characteristics of these guest rooms are the elevated floor throughout the walls where the klines are placed.

The prostas and pastas are identical spaces in terms of function and location, but houses containing these spaces are interpreted as two different types. Although there are differences between these types, the distinction does not originate from the prostas/pastas. The most outstanding difference is that at the prostas house, oikos is the dominant space of the house forming the focal point, while in the pastas house there are two or more rooms passed through the pastas, sometimes hard to understand which one is the oikos. Generally the origin of these two types are attributed to different roots which leads to the thought that the roots of prostas and pastas are also different from each other. Özgenel [26] states that the two are only local variations of the same plan type (prostas is matched with Anatolia while pastas is with Greece, but there are remains of both in both lands), and also Graham [10] binds the root of the two to megaron.

During excavations, the okios is identified by its size, central hearth if there is one, daily household goods, cooking pots and the location in the house while the andron is recognized by its elevated floor, elaborate decoration and nearly square plan [26]. The workshops and shops are recognized by the goods, quarters and tools specific to a craft. But there is not a specific tool, special goods or construction to guide the identification of gynaikonitis and thalamos if they exist. So these spaces are mostly defined by the help of ancient texts, eventually there is no concurrence on neither the existence nor the location of these spaces.

\subsection{Thalamos}

Thalamos, the bedroom, is considered to be situated at the second floor. During excavations, it is difficult to identify the second floor because the wooden material, solid, floor and the materials from the roof usually meld together and it 
is difficult to distinguish which ones are from the upper floor. Also it is usually not clear whether an object has fallen from the second floor or not. The guidance of the stairs is not also reliable as wooden stairs are very common [7].

It is not for certain when the first thalamos appeared. In single roomed house, oikos is also the place where the family sleeps at night. These houses have sleeping platforms adjacent to the walls [20]. In a 8th Century house in Emporio (in Chios), there is a room containing such platforms, adjacent to a megaron [27]. These structures can be separate units as Snodgrass [27] suggests, but it is also probable that this room and the megaron are forming a house complex, and the megaron is the oikos while the room with the platforms is the thalamos.

\subsection{Gynaikonitis}

Ancient houses having a "men's quarter" leads to the thought that there should also be a "women's quarter". The source of this assumption is ancient texts rather than archeological finds. Ksenophon [28] and Lysias [29], both writers of 4th Century AD, write about the andron and gynaikonitis and the separation of these spaces. Ksenophon tells these spaces are separated by a sliding door, while Lysias writes the andron is downstairs and gynaikonitis is upstairs. However, it is not for certain if these passages talk about the truth or an ideal situation [30].

Because of the suspicious objectivity of ancient texts and lack of archaeological finds, some researchers claim that there is no such a great distinction between these places [7, 26, 30], while others [20] claim that there should be, referring the social structure and legal arrangements of Greek society.

The function of gynaikonitis is also problematic. It is not for certain if this room is a place where women host their female guests, or do daily housework. If this place is a working space, then the labor that the women spend most of their time, the weaving, should be done here. But the spindle whorls are found in almost every room in the houses of Olynthus, which proves that there is not a fixed place where women work.

\section{Social structure}

\subsection{Family structure}

Some researchers define the house space as female, while the city (polis) as male [30]. The interior is identified with Hestia, Goddess of hearth, stability and immobility, while the outside is identified with Hermes, God of movement and communication, and protector of the boundary between the two [7]. However this judgement defines an ideal situation and it is not clear how this distinction is reflected to daily life. Ancient texts tell that men should interfere with labors outside and play an active role in public, while women should do the housework and stay away from social life. Ksenophon [28] binds this situation to the different natures of man and woman. However it is not possible to know whether Ksenophon is objective, or only writes what he believes in [30]. So many researchers are suspicious about a spatial distinction between women and men. 
In Geometric and Archaic eras when the houses are usually single-spaced, one cannot expect to encounter a gender specific area [20], while at later eras, in the multi-room houses significantly the only gender specific space is the andron.

Some legal arrangements also tell about the situation of women. The women cannot vote, and are not citizens. This can be a proof that women are isolated from the political life, whereas there is not enough evidence to claim that they are also isolated from the social life. Even if they are, this isolation cannot be traced in the space organization of houses. According to archaeological remains, women use all spaces of the house, and the space organization is not to separate women and men but to separate women of the house from the male guests. There is no very isolated places, and every room can be reached easily from the court. So the ancient Greek house does not reflect the unproven social distinction of man and woman $[7,26]$.

\subsection{Political structure}

The political organization of Ancient West Anatolia is in terms of autonomous city states, which did not form a political unity until the Hellenistic Period. Although the development process of democracy can be traced in Athens from 7 th Century $\mathrm{AD}$ and on, for the cities of Anatolia it is not clear at what phase there has been democracy, or even there has been until the Helenistic Era. However, even through the reign of Persian satraps, they must have been influenced from the equality ideas in Athens, at least at intellectual level.

In the monarchic and oligarchic administrations, the akropol is the religious and political center of the city, and the transition to democracy shifts the political center from the akropol to the agora [31]. In aristocracy the political power is symbolized with the house of the sovereign, which is placed at the akropol. Whereas from the Classical times on, public buildings represent the political authority and cover vast spaces in the city. For example in Priene, the $30-40 \%$ of the whole city is devoted to public buildings.

The limited archeological ruins indicates that in the Geometric Era, the only function of the house of the sovereign was domestic, while from the Archaic times on, the administrative and domestic functions were gathered in one building by the help of a court, probably with Persian influence. This schema, which houses the andron as the political authority symbol, became the common structure of the houses of general public in the Classical Period, which can be interpreted as an effect of the democratization process. The sharing of the political power has swept away the differences of houses of people and governor.

The equal parcelization of housing insulaes, gardens, fields and necropols in a newly established city is called isomoiria (equal share) [32]. The grid system of identical housing blocks and type houses, first encountered in Pire in 5th Century $\mathrm{AD}$ and later has been applied in Priene, Herakleia, Knidos, Magnesia in 4th Century, are considered to be the reflection of equality idea of democracy to architecture [23]. But although the insulaes are equal in size, there is no evidence to prove that the houses are identical too. It is known that not all the houses in Olynthus are the same, and the reconstruction of Pire and Priene houses are the synthesis of different parts of two or more houses [32], so there is no proof to 
claim that the houses were completely equal. Nevertheless, isomoiria can be considered as the effect of democracy to town planning, whereas the equal parcelization of the land could also have been preferred for practical reasons, as the grid plan is fast and easy. People of Milet reconstructing a demolished city, and people of Athens in need of a coastal town (Pire) for the upcoming war had to be quick. But the realization of this plan by other cities in the following centuries also shows that the democracy and equality ideas could have played a role for the adoption of grid plan.

\section{Conclusion}

Most problematic of the studies on Ancient domestic architecture originate from the inefficiency of archeological ruins. The remains differ in quantity, quality (well-preserved or not) and degree of documentation according to cities. Especially the comparison of houses in different cities leads to dubious conclusions as the data are not equal. As the houses of Olynthus and Priene are well preserved, many in number, and well-documented, they are interpreted as main types, and the Classical house is evaluated in terms of these examples in most publications. Though the houses of Latmos or Milet, although dated to the same century, are not such well-preserved and not so broadly documented. There is about 100 houses uncovered in Olynthus, while there is only 3 which gives a complete plan in Colophon. Besides, there is not a single city that all the ages of domestic architecture can be documented with the help of ruins. So ruins of different ages from different cities are brought together to form a unity. So to say, the state of the archeological ruins and the degree of documentation complicate defining house typologies and comparing houses of different cities.

The observation and interpretation of houses usually remain at the plan level, as there is so limited number of houses that the walls have stayed up to a considerable level to give an opinion of the whole. Even though the existence of the second floor is proven, the material and function of the space cannot always been understood, so generally the reconstructions are highly speculative.

Classification is inevitable to interpret house structures, but the newly explored ruins are sometimes not evaluated independently but in terms of existing prostas and pastas typologies, while the earlier houses are interpreted as the phases of an evolution leading to these types.

The house is an architectural structure that is most bound to user initiative and local traditions. Also, house spaces can vary function from time to time, so the typologies are not always significant. The nature of domestic architecture complicates research and studies on the subject.

The houses are usually evaluated disconnectedly from public and religious buildings of the city. The transformation of public buildings can be collateral to the transformation of housing space although not directly linked. For example there is such a parallelism between city plans and houses, the systematization of both are in the same period. It is not improper to suppose that the social structure effecting the plan of the city also effects the architecture of the houses. For example in Olynthus, the same parcelization system of the city is also applied for 
the organization of the houses, the Olynthus house is divided within itself like the city parcels [2]. Besides, Classical Greek Architecture aims to regulate and idealize the existing practice rather than practising new experiments. Greek domestic architecture has also developed an existing construction, and carried the two room and a court Archaic house to the Hellenistic multi-roomed peristyl house conserving the schema of rooms enclosing a court. Then, if the changes in social structure are effecting the organization of the city and public buildings, these effects can also be invested in domestic architecture to illuminate unexplained situations.

\section{References}

[1] Wiegand, Th. \& Schrader H., Priene, Ergebnisse der Ausgrabungen und Untersuchungen in den Jahren, 1895-1898, G. Reimer: Berlin, 1904

[2] Robinson, D. M. \& Graham J. W., The Hellenic House, A Study of the Houses Founded at Olynthus with a detailed account of those excavated in 1931 and 1934, Excavations at Olynthus Part 8, Johns Hopkins: Baltimore, 1938

[3] Abbasoğlu, H., Antiquity Dwellings in Anatolia. Housing and Settlement in Anatolia: A Historical Perspective, ed. Sey, Y., Tarih Vakfı Yayınları: İstanbul, pp. 395-404, 1996

[4] Akurgal, E., Eski İzmir 1, Yerleşme Katları ve Athena Tapınağı, Türk Tarih Kurumu Basım Evi: Ankara, 1983

[5] Akurgal, E., Housing, Settlement and Urban Planning in Western Anatolia (3000- 30 BC). Housing and Settlement in Anatolia: A Historical Perspective, ed. Sey, Y., Tarih Vakfi Yayınları: İstanbul, pp. 122-143, 1996

[6] Drerup, H., Prostashaus und Pastashaus: Zur Typologie des griechischen Hauses. Marburger Winckelmann-Programm, pp. 6-17, 1967

[7] Jameson, M. H., Domestic Space in the Greek City-State. Domestic Architecture and the Use of Space: An Interdisciplinary Cross-Cultural Study, ed. Kent. S., Cambridge University Press: Cambridge, pp. 92-113, 1990

[8] Özgenel, L., Antik Dönem Evleri ve Sahipleri, Batı Anadolu'daki İyon Konutlar1. Arkeoloji ve Sanat, 78, pp. 14-24, 1997

[9] Sinos, S., Die Vorklassischen Hausformen in der Ägäis, Verlag Philipp von Zabern: Mainz am Rhein, 1971

[10] Graham, J. W., Origins and Interrelations of the Greek House and the Roman House. Phoenix, 20, pp. 3-31, 1966

[11] Krause, C., Grundformen des Griehischen Pastashaus. Archäologischer Anzeiger, pp. 164-179, 1977

[12] Gürler, B., Passing to the Prostas Type House in West Anatolia and the Location of this Type in the City Planning. Çağlar Boyunca Anadolu'da Yerleşim ve Konut Uluslararası Sempozyumu-Bildiriler, ed. Dinçol, A. M., Ege Yayınlar1: İstanbul, pp. 231-240, 1999

[13] Lawrence, A. W., Greek Architecture, Penguin Books: London, 1967 
72 Structural Repairs and Maintenance of Heritage Architecture XII

[14] Naumann, R., Eski Anadolu Mimarlı̆̆l, Türk Tarih Kurumu Basımevi: Ankara, 1975

[15] Klazomenai Archaeological Excavation Web Site, http://www.klazomeniaka.com/05-KLAZOMENAI-GEC-ARKAIK.htm

[16] Kolb, F. \& Thomsen, A., Arbeiten auf dem Avşar Tepesi. 17. Araştırma Sonuçları Toplantısı, T.C. Kültür Bakanlığı: Ankara, pp. 221-234, 1999

[17] Peschlow-Bindokat, A., Herakleia Am Latmos Stadt und Umgebung, Homer Kitabevi: İstanbul, 2005

[18] Ramage, A., Lydian Houses and Architectural Terracottas, Archaeological Exploration of Sardis, Monograph 5, Harvard University Press: Cambridge, 1978

[19] Senff, R., Die Grabung am Kalabaktepe. Archäologischer Anzeiger, pp. 208-213, 1995

[20] Hoepfner, W., Houses and Society in Classical Antiquity. Housing and Settlement in Anatolia: A Historical Perspective, ed. Sey, Y., Tarih Vakfi Yayınlar1: İstanbul, pp. 155-164, 1996

[21] Holland, L. B., Colophon. Hesperia, 13, pp. 123-147, 1944

[22] Schefold, K. \& Boehlau, J., Larisa am Hermos, der Ergebnisse der Ausgrabungen 1902- 1934, Band 1: die Bauten, Verlag Walter de Gruyter \& Co: Berlin, 1940

[23] Hoepfner, W. \& Schwandner, E. L., Haus und Stadt im Klassischen Griechenland, Deutscher Kunstverlag: München, 1994

[24] Thomsen, A., Die Lykische Dynastensiedlung auf dem Avşar Tepesi, Dr. Rudolf Habelt GmbH: Bonn, 2002

[25] Kiegeland, J., Wie Wohnten die Tyrannen?. Die Griechische PolisArchitektur und Politik, ed. Hoepfner, W. \& Zimmer, G., Ernst Wasmuth Verlag: Tübingen, pp. 46-57, 1993

[26] Özgenel, L., Anadolu'daki Yunan Dönemi Konutlarında Mekan Tanımı, Kullanımı ve Cinsiyet. Olba, Kilikia Arkeolojisini Araştırma Merkezi Yayınlarl, 4, pp. 125-143, 2001

[27] Snodgrass, A. M., The Dark Age of Greece, Edinburg University Press: Edinburgh, 2000

[28] Ksenophon, Oikonomikos, trans. Pomeroy, S. B., Oxford University Press: New York, 9.2-5 and VII-22, 1994

[29] Lysias, The Orations of Lysias (Orationes), trans. Lamb, W. R. M., Harvard University Press: Cambridge, 1, 9-10, 1957

[30] Nevett, L. C., House and Society in the Ancient Greek World, Cambridge University Press: Cambridge, 1999

[31] Wycherley, R. E., Antik Çă̆da Kentler Nasıl Kuruldu?, Arkeoloji ve Sanat Yayınları: İstanbul, 1993

[32] Hansen, H. H., Diskussion. Demokratie und Architektur, Der hippodamische Städtebau und die Entstehung der Demokratie, ed. Schuller, W., Deutscher Kunstverlag: München, pp. 15 ve 113, 1989 